\title{
University Reactor Conversion Lessons Learned Workshop for Purdue University Reactor
}

Eric C. Woolstenhulme Dana M. Hewit

September 2008
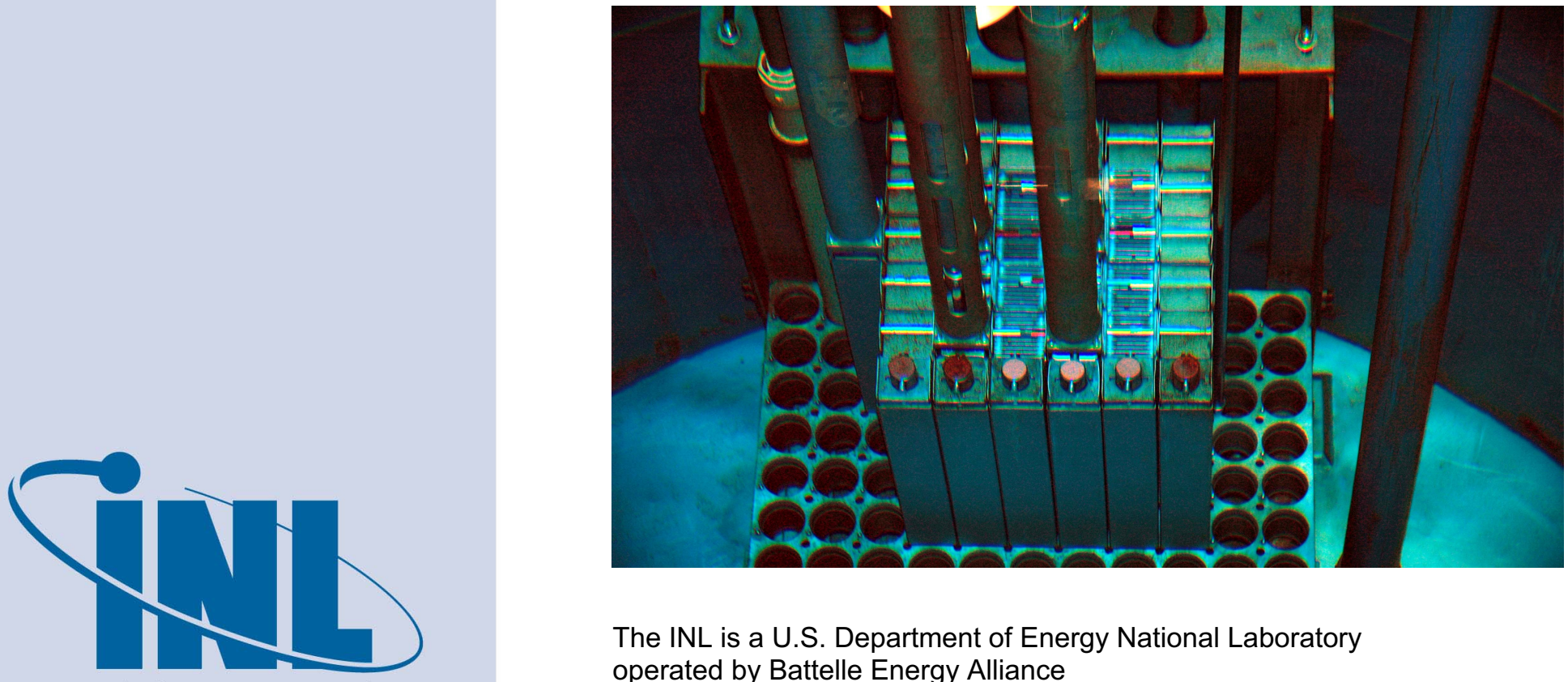

Idaho National Laboratory

The INL is a U.S. Department of Energy National Laboratory operated by Battelle Energy Alliance 
INL/EXT-08-14856

\title{
University Reactor Conversion Lessons Learned Workshop for Purdue University Reactor
}

\author{
Eric C. Woolstenhulme \\ Dana M. Hewit
}

September 2008

Idaho National Laboratory
Idaho Falls, Idaho 83415

http://www.inl.gov

Prepared for the

U.S. Department of Energy

Office of National Nuclear Security Administration

Under DOE Idaho Operations Office

Contract DE-AC07-05ID14517 



\begin{abstract}
The Department of Energy's Idaho National Laboratory, under its programmatic responsibility for managing the University Research Reactor Conversions, has completed the conversion of the reactor at Purdue University Reactor. With this work completed and in anticipation of other impending conversion projects, the INL convened and engaged the project participants in a structured discussion to capture the lessons learned. The lessons learned process has allowed us to capture gaps, opportunities, and good practices, drawing from the project team's experiences. These lessons will be used to raise the standard of excellence, effectiveness, and efficiency in all future conversion projects.
\end{abstract}




\section{CONTENTS}

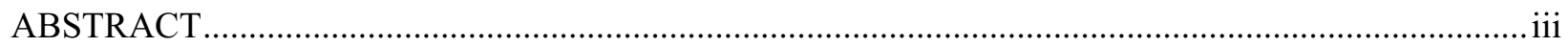

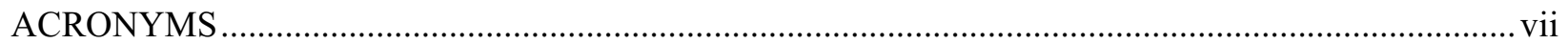

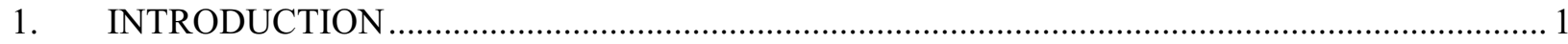

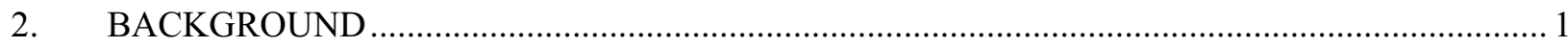

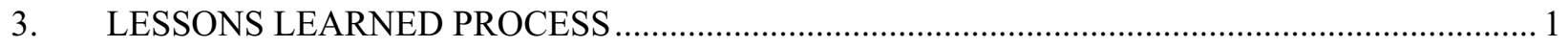

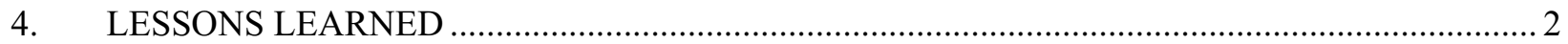

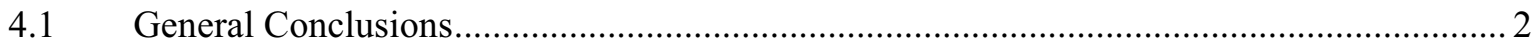

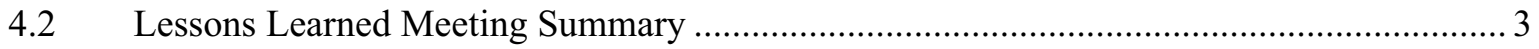

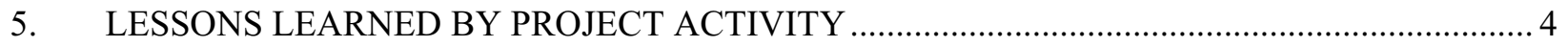

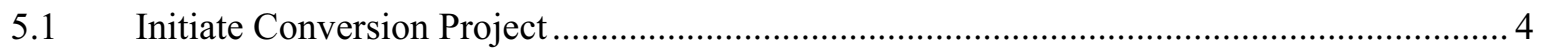

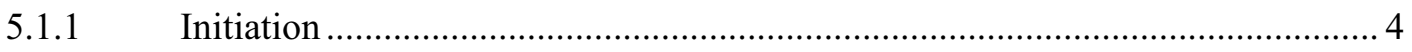

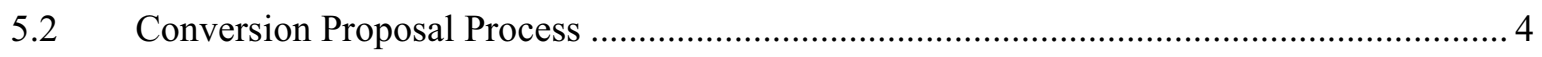

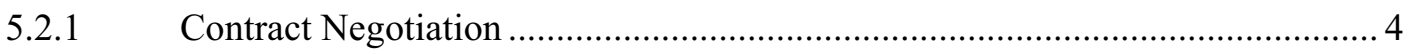

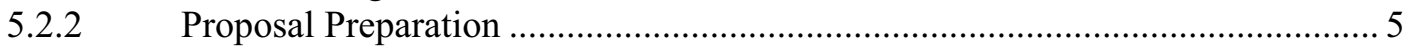

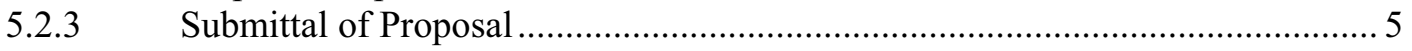

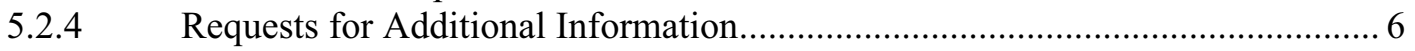

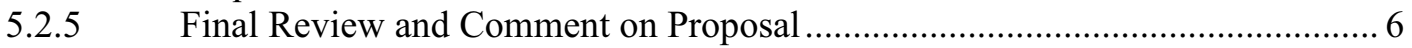

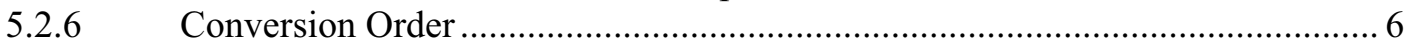

5.3 Fuel and Hardware Development and Procurement ................................................... 6

5.3.1 Possession Limits Increase Request ............................................................ 7

5.3.2 Fuel Specifications and Drawings................................................................. 7

5.3.3 Fuel Fabrication Statement of Work and Procurement Documents .................... 8

5.3.4 Fuel Fabrication (schedule, changes, process) ............................................ 9

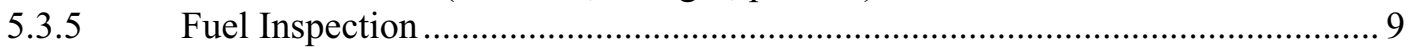

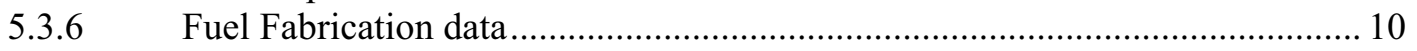

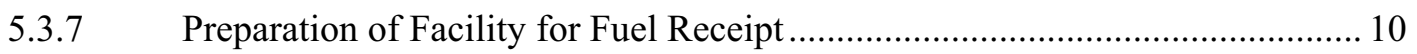

5.3.8 Fuel Delivery Arrangements (from fabricators to universities) ......................... 10

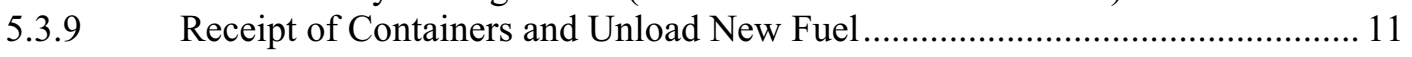

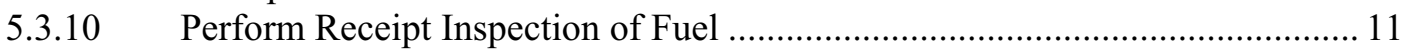

5.3.11 Reassembly Shipping Containers for Return .............................................. 11

5.3.12 Fuel Assembly Hardware Receipt and Installation ......................................... 11

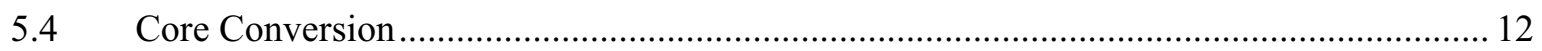

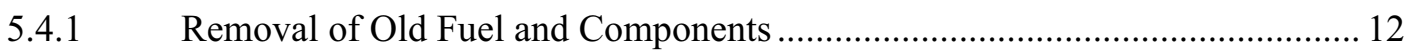




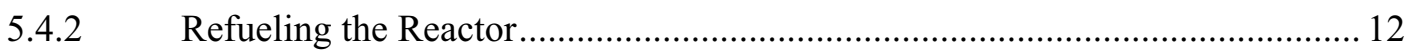

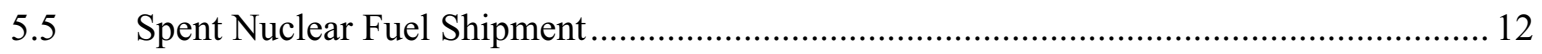

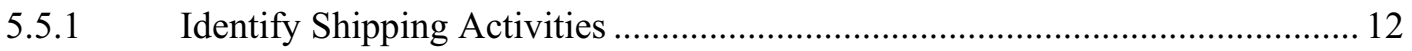

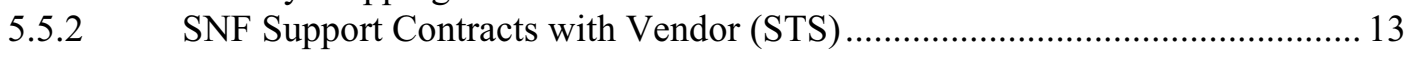

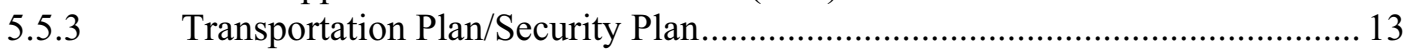

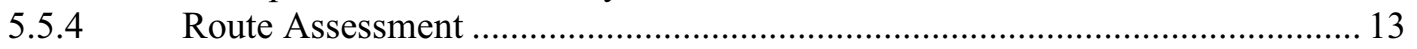

5.5.5 Certification of Reactor Quality Assurance Programs .................................... 14

5.5.6 Facility Preparations for Spent Nuclear Fuel Activities ................................... 14

5.5.7 Support Equipment/Tools for Spent Nuclear Fuel Activities ........................... 14

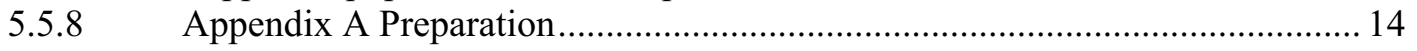

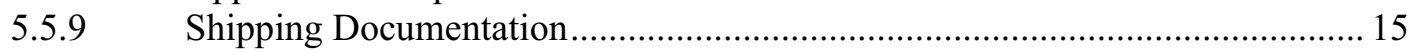

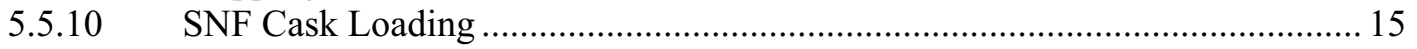

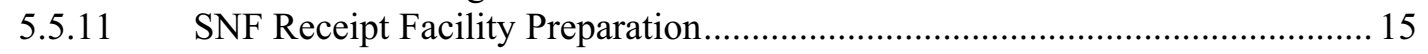

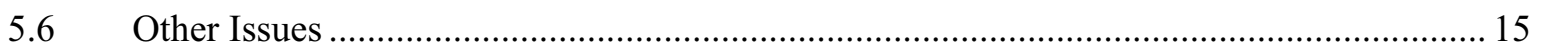

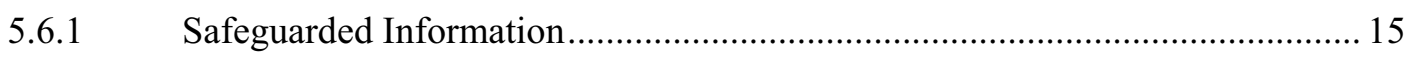

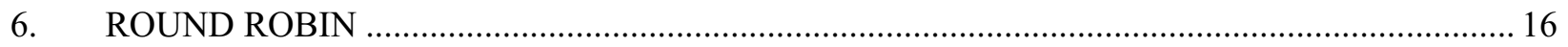

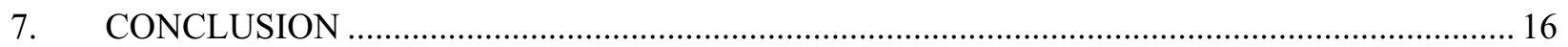




\section{ACRONYMS}

ANL Argonne National Laboratory

DOE U.S. Department of Energy

GA General Atomics

HEU highly enriched uranium

INL Idaho National Laboratory

LEU low-enriched uranium

NNSA National Nuclear Security Administration

NRC Nuclear Regulatory Commission

ORIGEN ORNL (Oak Ridge National Laboratory) Isotope Generation and Depletion Code

POC Point of contact

RFP Request for proposal

SNF spent nuclear fuel

SOW Statement of Work

STS Secured Transportation Services Inc.

T\&FR Technical and Functional Requirements 


\section{University Reactor Conversion Lessons Learned Workshop for Purdue University Reactor}

\section{INTRODUCTION}

The Department of Energy's (DOE) Idaho National Laboratory (INL), under its programmatic responsibility for managing the University Research Reactor Conversions, has completed the conversion of the reactor at Purdue University. This project was successfully completed through an integrated and collaborative effort involving INL, Argonne National Laboratory (ANL), DOE (headquarters and the field office), the Nuclear Regulatory Commission (NRC), the universities, and the contractors involved in analyses, fuel design and fabrication, and spent nuclear fuel (SNF) shipping and disposition. With this work completed and in anticipation of other impending conversion projects, the INL convened and engaged the project participants in a structured discussion to capture the lessons learned. The objectives of this meeting were to capture the observations, insights, issues, concerns, and ideas of those involved in the reactor conversions so that future efforts can be conducted with greater effectiveness, efficiency, and with fewer challenges.

\section{BACKGROUND}

As part of the Bush Administration's effort to reduce the amount of weapons-grade nuclear material worldwide, the National Nuclear Security Administration (NNSA) has established a program to convert research reactors from using highly enriched uranium (HEU) to low-enriched uranium (LEU) fuel.

The research reactor conversion effort is a critical step under the Global Threat Reduction Initiative's Reduced Enrichment for Research and Test Reactors program. As part of this program, NNSA is minimizing the use of HEU in civilian nuclear programs by converting research reactors and radioisotope production processes to the use of LEU fuel and targets. The HEU is weapons-grade nuclear material that could be used to make a nuclear weapon or dirty bomb. The US based research reactors are secure and are used for peaceful purposes, however, by converting the reactors to use LEU, a significant step is made toward ensuring that the HEU more secure and better safeguarded. Purdue University Reactor was the reactors targeted for HEU conversion in 2007.

Reactor conversions include analyses, LEU fuel fabrication, reactor defuel and refuel activities, HEU spent nuclear fuel packaging and transportation, and reactor startup.

\section{LESSONS LEARNED PROCESS}

The process for capturing the lessons learned from this project involved taking the schedule of the project activities and focusing feedback and discussion on each respective activity. The feedback and lessons learned discussions were held in an open discussion workshop, including all participating team members and their representatives. To promote a more expedient discussion at the workshops and to help the project team focus on the higher priority areas, a survey was developed and sent to project participants before the workshops. The survey invited those involved to score and offer comments with regard to the projects activities in which they were involved. The survey was formatted with a 5-point Likert scale, where 1 was low or "extremely challenging" and 5 was high or "exceptional." The surveys were collected and scores were entered and averaged for each activity. The average score for each activity is identified in Section 5 of this document. 
Based on survey scores and comments, the workshop agenda was established and timeframes were estimated. Consistent with expectations based on the survey results, the workshop discussions were brief for the unremarkable areas and more extended and detailed in those areas of greatest significance. The detailed lessons learned were captured and the themes and general conclusions were then drawn. The general conclusions and themes tend to apply to all activities (almost as operating principles) and will benefit future project teams and project managers. The more detailed lessons learned align to given activities and apply to the project manager and those involved in the given activity, as that activity is undertaken.

\section{LESSONS LEARNED}

\subsection{General Conclusions}

This project was clearly a success. Nonetheless, there were many detailed lessons learned regarding both technical and project management aspects. The specifics are provided in the following sections, however, some general elements are key to the success of future conversion and spent fuel shipping projects. Future projects will be conducted most effectively, efficiently, and with a minimum of risks, interference, and interruptions if the following are an integral part of the project:

- $\quad$ Project team composition which includes a project team composed of individuals who are critical thinkers, flexible, and committed to the project results. As noted by a project team member:

"Having the right people who were willing to buy into the common vision and mission was critical. Everyone had a great personal work ethic. Having a single point of contact (POC) who is dedicated to the project [allowing that person to stay in contact with all parties involved and to identify and track issues] was instrumental in the success of the project.

- Communication including inclusive communications and exchange that provides for effective sharing of needs, expectations, roles, responsibilities, data, assumptions, schedules, and facility and equipment constraints.

- Use of expertise including confidence in and effective utilization of the varied expertise and experience of the team members.

- $\quad$ Proactivity and individual levels of initiative.

- $\quad$ Early initiation including the earliest possible initiation of planning and activities at every step in the project process, thereby minimizing the likelihood of time-critical situations.

- Verification and re-verification of data, analyses, specifications, assumptions, performance expectations, and equipment fit and function throughout the project.

- Clear and common understanding including clear expectations of roles, responsibilities, technical variables, and technical results.

- Knowledgeable and informed stakeholders who can advocate for the project, remove barriers, and support decisions and adjustments needed to ensure project success (e.g., public, political, and administrative).

- Compile reactor data including assembly or compilation of the historical documents that reveal what is known and unknown about the reactor.

- Value-added government oversight in which the public interests are served, objectivity is retained, but NRC's experience and expertise is available to the project. 
The above list comprised the general themes of the lessons learned meeting. The detailed lessons learned were discussed in the order of project activities, from initiation to closeout, and are provided in the following sections.

\subsection{Lessons Learned Meeting Summary}

The Lessons Learned Workshop for Purdue University Reactor convened on March 18, 2008, at the University of Central Florida facilities in Orlando, Florida. The following were attendees at the workshop:

\author{
Dana Hewit, INL \\ Eric Woolstenhulme, INL \\ Vic Pearson, DOE-ID \\ Chip Shaffer, BWXT \\ John Stillman, ANL
}

\author{
William Schuster, NRC \\ John Creasy, NNSA \\ Alexander Adams, NRC \\ Jere Jenkins, Purdue \\ Blake Williams, STS
}

The following was the agenda for the workshop:

9:00 Welcome and introductory remarks

- $\quad$ Establish ground rules and review agenda

9:15 Discuss and collect lessons learned by each major activity area

- Initiating Conversion Project

- Conversion Proposal Process

10:45 Break

11:00 Discuss and collect lessons learned by each major activity area (continued)

- $\quad$ Fuel and Hardware Development and Procurement

12:00 Lunch

1:00 Discuss and collect lessons learned by each major activity area (continued)

- Core Conversion

- $\quad$ SNF Shipment

2:30 Break

2:45 Discuss and collect lessons learned by each major activity area (continued)

- $\quad$ Other areas needing to be addressed

3:15 Meeting Summary - Actions

3:30 Closing remarks - Round Robin

4:00 Adjourn 


\section{LESSONS LEARNED BY PROJECT ACTIVITY}

The detailed lessons learned were discussed in order of project activities, from initiation to closeout, and are provided in the following sections.

\subsection{Initiate Conversion Project}

\subsubsection{Initiation}

The average survey score was 4.17.

\begin{tabular}{|l|l|}
\hline \multicolumn{1}{|c|}{ Issues } & \multicolumn{1}{|c|}{ Recommendations } \\
\hline $\begin{array}{l}\text { Initial visits to university reactor personnel were } \\
\text { very beneficial, but did not include all of the } \\
\text { university management people needed to ensure } \\
\text { the process ran smoothly. There was not a mutual } \\
\text { understanding of the importance of making } \\
\text { preparations to perform some of the work scope. }\end{array}$ & $\begin{array}{l}\text { A valuable lesson learned in this regard was for } \\
\text { the program to understand who all the players are } \\
\text { and to involve them in a full force visit to the } \\
\text { university to ensure a mutual understanding of the } \\
\text { total scope. University management should be } \\
\text { informed of the schedule and resource needs. } \\
\text { Spent Nuclear Fuel personnel should be involved } \\
\text { in the initial planning meetings. }\end{array}$ \\
\hline
\end{tabular}

\subsection{Conversion Proposal Process}

\subsubsection{Contract Negotiation}

The average survey score was 3.50 .

\begin{tabular}{|l|l|}
\hline \multicolumn{1}{|c|}{ Issues } & \multicolumn{1}{|c|}{ Recommendations } \\
\hline $\begin{array}{l}\text { Purdue was not prepared for the contract } \\
\text { negotiations to happen within such short time } \\
\text { windows. }\end{array}$ & $\begin{array}{l}\text { Encourage procurement/contracts to be proactive } \\
\text { and regularly check on the contract progress. }\end{array}$ \\
\hline $\begin{array}{l}\text { INL procurement was not straightforward and } \\
\text { there was a lack of guidance for preparation of the } \\
\text { cost estimates and basis information for the } \\
\text { contract. }\end{array}$ & $\begin{array}{l}\text { Clearly define procurement/contracts roles and } \\
\text { responsibilities of the participants so there is an } \\
\text { understanding of the goals and associated dates. }\end{array}$ \\
\hline $\begin{array}{l}\text { Having two separate contracts for the conversion } \\
\text { and for SNF shipping is cumbersome. The } \\
\text { activities are closely related and it is difficult to } \\
\text { quote the scope separately. }\end{array}$ & $\begin{array}{l}\text { The combining of the contracts is not an option } \\
\text { because of the 2 separate funding sources and the } \\
\text { separate time frames for the activities. }\end{array}$ \\
\hline
\end{tabular}




\subsubsection{Proposal Preparation}

The average survey score was 4.0.

\begin{tabular}{|l|l|}
\hline \multicolumn{1}{|c|}{ Issues } & \multicolumn{1}{|c|}{ Recommendations } \\
\hline $\begin{array}{l}\text { Conversion Proposal information was submitted } \\
\text { to the NRC with some discrepancies, requiring a } \\
\text { more detailed review by the NRC. }\end{array}$ & $\begin{array}{l}\text { Conduct an independent review of the Conversion } \\
\text { Proposal submittal prior to sending to the NRC. }\end{array}$ \\
\hline $\begin{array}{l}\text { Although a schedule was provided for the } \\
\text { upcoming activities, including the review of the } \\
\text { Conversion Proposal, university upper } \\
\text { management was not prepared for the impact on } \\
\text { resources. }\end{array}$ & $\begin{array}{l}\text { Engage university upper management early in the } \\
\text { process to help ensure an understanding of the } \\
\text { resources (staff man hours) required for the scope } \\
\text { of the work. }\end{array}$ \\
\hline $\begin{array}{l}\text { Conversion Proposal preparation went well with } \\
\text { good cooperation and support from team } \\
\text { members. There was abundant interaction back } \\
\text { and forth with a clear, comprehensive plan and } \\
\text { identification of who was responsible for what. }\end{array}$ & $\begin{array}{l}\text { Continue to embrace a collaborative and } \\
\text { interactive operating philosophy, yielding } \\
\text { constructive and clear communication and } \\
\text { exchange. }\end{array}$ \\
\hline
\end{tabular}

\subsubsection{Submittal of Proposal}

The average survey score was 3.67.

\begin{tabular}{|l|l|}
\hline \multicolumn{1}{|c|}{ Issue } & \multicolumn{1}{|c|}{ Recommendations } \\
\hline $\begin{array}{l}\text { Making changes to the design after the } \\
\text { Conversion Proposal safety analysis was } \\
\text { submitted to NRC created delays for the project. } \\
\begin{array}{l}\text { There was a tight schedule and tasks were being } \\
\text { done simultaneously. }\end{array}\end{array}$ & $\begin{array}{l}\text { Complete the design before preparing the } \\
\text { Conversion Proposal. This will ensure the correct } \\
\text { design specifications are included. The proposal } \\
\text { can then move forward with significantly } \\
\text { minimized risk. }\end{array}$ \\
\hline $\begin{array}{l}\text { There were delays in the process. Changes were } \\
\text { occurring in the Possession Order at NRC. } \\
\text { Optimism about not needing a Possession Order } \\
\text { makes it a risk to the project schedule. }\end{array}$ & $\begin{array}{l}\text { Receive notification from the NRC of all } \\
\text { support their review of the analyses. } \\
\text { Possession Order is needed, submit it as early as } \\
\text { possible. }\end{array}$ \\
\hline $\begin{array}{l}\text { A lesson learned from the Florida fuel resulted in } \\
\text { a much-improved fuel element design for Purdue. } \\
\text { Many of the safety analyses were redone in the } \\
\text { RAI Phase to accommodate the change in fuel } \\
\text { element design. }\end{array}$ & $\begin{array}{l}\text { Continue distribution of the lessons learned from } \\
\text { other conversion projects as early as possible. }\end{array}$ \\
\hline
\end{tabular}




\subsubsection{Requests for Additional Information}

The average survey score was 3.5.

\begin{tabular}{|l|l|}
\hline \multicolumn{1}{|c|}{ Issues } & \multicolumn{1}{|c|}{ Recommendations } \\
\hline $\begin{array}{l}\text { No deficiencies were discussed - the process } \\
\text { worked well. }\end{array}$ & $\begin{array}{l}\text { After issuing the request for additional } \\
\text { information, NRC visited the University to } \\
\text { discuss their resolutions/dispositions to the } \\
\text { questions. This was extremely effective and } \\
\text { worked to expedite the question resolution } \\
\text { process. }\end{array}$ \\
Continue this practice.
\end{tabular}

\subsubsection{Final Review and Comment on Proposal}

The average survey score was 4.33 .

\begin{tabular}{|l|l|}
\hline \multicolumn{1}{|c|}{ Issues } & \multicolumn{1}{|c|}{ Recommendations } \\
\hline $\begin{array}{l}\text { The conference call held before publishing the } \\
\text { RAI was very important. The site visit by the } \\
\text { NRC to discuss the RAI resolutions was very } \\
\text { useful. }\end{array}$ & $\begin{array}{l}\text { Continue these practices with the licensee hosting } \\
\text { a pre-RAI teleconference with the NRC. The } \\
\text { licensee will determine who should be involved in } \\
\text { the teleconference. }\end{array}$ \\
& Notify ANL of the RAI reviews. \\
\hline
\end{tabular}

\subsubsection{Conversion Order}

The average survey score was 3.25 .

\begin{tabular}{|l|l|}
\hline \multicolumn{1}{|c|}{ Issue } & \multicolumn{1}{|c|}{ Recommendation } \\
\hline $\begin{array}{l}\text { Everyone involved in the project must be sensitive } \\
\text { to workload and time constraints and work to the } \\
\text { schedule. The NRC schedule is planned and the } \\
\text { information needs to be to them as scheduled. }\end{array}$ & $\begin{array}{l}\text { Provide support to ensure that applications to the } \\
\text { NRC are complete, accurate, and timely. }\end{array}$ \\
$\begin{array}{l}\text { Some required signoffs are outside the control of } \\
\text { the NRC POC. }\end{array}$ & \\
\hline
\end{tabular}

\subsection{Fuel and Hardware Development and Procurement}

NOTE: Many of the fuel and hardware fabrication issues were discussed with regard to collaboration and clarification between designers and fabricators. Communication and misunderstandings appear to be the biggest issue. Designers and fabricators (and analysts) need to talk openly and often. Inclusive (i.e., all parties) communication is critical. 


\subsubsection{Possession Limits Increase Request}

The average survey score was N/A.

\begin{tabular}{|c|c|}
\hline Issues & Recommendations \\
\hline $\begin{array}{l}\text { The fuel plates were shipped earlier than originally } \\
\text { planned to allow the reactor personnel time to } \\
\text { assemble them. This required a separate Order } \\
\text { from the NRC to increase the possession limit. The } \\
\text { Possession Order request did not get to the NRC as } \\
\text { early as they would have liked, so it forced the } \\
\text { schedule for NRC. The NRC was able to support } \\
\text { the need date. }\end{array}$ & $\begin{array}{l}\text { Submit the possession limits increase request to the } \\
\mathrm{NRC} \text { as early as possible. If the Conversion Order } \\
\text { is anticipated after July } 31^{\text {st }} \text {, the possession limit } \\
\text { should be applied for. }\end{array}$ \\
\hline
\end{tabular}

\subsubsection{Fuel Specifications and Drawings}

The average survey score was 2.00 .

\begin{tabular}{|c|c|}
\hline Issues & Recommendations \\
\hline $\begin{array}{l}\text { Discrepancies in the fuel design drawings were } \\
\text { found during the review of the RFP by the } \\
\text { fabricator. }\end{array}$ & $\begin{array}{l}\text { Document Technical and Functional } \\
\text { Requirements (T\&FR). Finalize drawings and } \\
\text { route through the design review process prior to } \\
\text { going to the fabricator. } \\
\text { Clearly document drawing spacing requirements } \\
\text { and tolerances. } \\
\text { Encourage the user to meet with the fabricator } \\
\text { prior to establishment of the final design. }\end{array}$ \\
\hline $\begin{array}{l}\text { The fuel fabrication process was started before the } \\
\text { fuel plate design was complete, causing a } \\
\text { cessation in the fuel plate fabrication cycle for } \\
\text { machine tooling/fixtures to accommodate the } \\
\text { design. The initial drawings were too preliminary } \\
\text { and this issue wasted time for the fuel fabricator. }\end{array}$ & $\begin{array}{l}\text { Document T\&FR and design drawings. } \\
\text { Finalize drawings and route through the design } \\
\text { review process prior to going to the fabricator. }\end{array}$ \\
\hline $\begin{array}{l}\text { The final fuel plate product serial numbering and } \\
\text { surface defects were not what the user had } \\
\text { anticipated. The new product did not match what } \\
\text { the customer was familiar with. }\end{array}$ & $\begin{array}{l}\text { Encourage/Arrange for a licensee visit to the fuel } \\
\text { fabricator to review and test samples of the fuel } \\
\text { plates to eliminate any 'surprises' when the } \\
\text { product is received. }\end{array}$ \\
\hline
\end{tabular}




\begin{tabular}{|l|l|}
\hline \multicolumn{1}{|c|}{ Issues } & \multicolumn{1}{c|}{ Recommendations } \\
\hline $\begin{array}{l}\text { There were no specifications on the height or } \\
\text { quality of the fuel plate serial numbers or the } \\
\text { quality of the surface finish. The customer needs } \\
\text { were not addressed in the specification; there were } \\
\text { verbal discussions but no follow through. }\end{array}$ & $\begin{array}{l}\text { Ensure the T\&FR address the customer } \\
\text { specifications for fuel plate spacing, flatness, } \\
\text { serial number size, and surface finish, if required. }\end{array}$ \\
\hline $\begin{array}{l}\text { There was no capability for reactor personnel to } \\
\text { measure some of the specifications for the fuel } \\
\text { plates. Specifically, they had no way to measure } \\
\text { the depth of the pits or the quality of the finish } \\
\text { and had to rely on QA inspections performed by } \\
\text { INL and BWXT inspectors. }\end{array}$ & $\begin{array}{l}\text { Transmit the QA inspection plans to the } \\
\text { customers for review and comment. If needed, } \\
\text { arrange for customers to meet with the Quality } \\
\text { Inspector prior to fabrication to review the INL } \\
\text { process for inspection. This may include an } \\
\text { onsite visit to the fuel fabrication facility where } \\
\text { the customers can observe the QI activities. }\end{array}$ \\
\hline $\begin{array}{l}\text { The 50 mil plate (compared to the } 60 \text { mil) was } \\
\text { less sturdy than anticipated. }\end{array}$ & $\begin{array}{l}\text { The INL and BWXT QA inspectors are qualified, } \\
\text { certified inspectors meeting the NQA1 } \\
\text { requirements. }\end{array}$ \\
\hline $\begin{array}{l}\text { Arrange for a customer visit to the fuel fabricator } \\
\text { plate for the reactor. }\end{array}$ \\
\hline
\end{tabular}

\subsubsection{Fuel Fabrication Statement of Work and Procurement Documents}

The average survey score was 2.0 .

\begin{tabular}{|l|l|}
\hline \multicolumn{1}{|c|}{ Issues } & \multicolumn{1}{|c|}{ Recommendations } \\
\hline $\begin{array}{l}\text { The fuel procurement specification documents } \\
\text { were developed late for the fuel container and } \\
\text { graphite container fabrication Statement of }\end{array}$ & $\begin{array}{l}\text { Involve the right people (project manager, } \\
\text { engineer) in the process earlier. }\end{array}$ \\
$\begin{array}{l}\text { Work (SOW). The SOW was later split to allow } \\
\text { for two separate fabrication contracts in order to } \\
\text { meet the required delivery date. Changes in the } \\
\text { scope of the SOW mandated that PUR assemble } \\
\text { the fuel elements at the reactor. This change } \\
\text { created issues of how and when to ship the fuel } \\
\text { plates to the reactor. Further, changes in the } \\
\text { quantity required additional certification and } \\
\text { inipping documents. }\end{array}$ \\
\hline
\end{tabular}




\begin{tabular}{|c|c|}
\hline Issues & Recommendations \\
\hline $\begin{array}{l}\text { Due to schedule, the fuel fabricator started } \\
\text { fabrication prior to final award and specification } \\
\text { approval, requiring unplanned reviews of } \\
\text { drawings and designs. }\end{array}$ & $\begin{array}{l}\text { Develop the T\&FR jointly so everyone involved } \\
\text { is fully aware of the final specifications. } \\
\text { The project should take a more active role in the } \\
\text { fuel fabrication. }\end{array}$ \\
\hline $\begin{array}{l}\text { This was a different fuel plate design than the } \\
\text { reactor personnel were familiar with. }\end{array}$ & $\begin{array}{l}\text { Ensure the preliminary meeting between all } \\
\text { parties (e.g., reactor personnel, analysts, } \\
\text { designers, and fabricators) occurs to discuss what } \\
\text { each party will get at each phase of the process. } \\
\text { These same parties should be included in status } \\
\text { and issues conversations throughout the process. } \\
\text { Communicate all requirements for analyses and } \\
\text { fabrication with all affected organizations. }\end{array}$ \\
\hline
\end{tabular}

\subsubsection{Fuel Fabrication (schedule, changes, process)}

The average survey score was 2.33 .

\begin{tabular}{|l|l|}
\hline \multicolumn{1}{|c|}{ Issues } & \multicolumn{1}{|c|}{ Recommendations } \\
\hline $\begin{array}{l}\text { Using a standard fuel plate helped the fabrication } \\
\text { process run smoothly. Process changes in the hole } \\
\text { size and location delayed final processing of plates. }\end{array}$ & $\begin{array}{l}\text { Develop the T\&FR needs jointly so everyone } \\
\text { involved is fully aware of the final specifications. }\end{array}$ \\
\hline
\end{tabular}

\subsubsection{Fuel Inspection}

The average survey score was 2.33 .

\begin{tabular}{|l|l|}
\hline \multicolumn{1}{|c|}{ Issues } & \multicolumn{1}{c|}{ Recommendations } \\
\hline $\begin{array}{l}\text { The fuel plate serial numbers were not at the } \\
\text { quality level that the licensee had anticipated. } \\
\begin{array}{l}\text { The fuel plate surface was not what was } \\
\text { anticipated. Purdue keeps the fuel for a number of } \\
\text { years and needs long-term serial number integrity. }\end{array}\end{array}$ & $\begin{array}{l}\text { Identify options for serial numbers. } \\
\text { Encourage/Arrange a licensee visit to the fuel } \\
\text { fabricator to review and test samples of the fuel } \\
\text { plates to eliminate any 'surprises' when the } \\
\text { product is received. }\end{array}$ \\
$\begin{array}{l}\text { Ensure the T\&FR address the customer } \\
\text { specifications for fuel plate spacing, flatness, } \\
\text { serial number size, and surface finish, if required. }\end{array}$ \\
\hline
\end{tabular}




\begin{tabular}{|l|l|}
\hline \multicolumn{1}{|c|}{ Issues } & \multicolumn{1}{|c|}{ Recommendations } \\
\hline $\begin{array}{l}\text { There were misunderstandings on the number of } \\
\text { plates that were to be shipped to the reactor, } \\
\text { resulting in two separate shipments. Further the } \\
\text { plates in the second shipment did not meet the } \\
\text { reactor's quality expectations. }\end{array}$ & $\begin{array}{l}\text { Involve project personnel, in details of the plates } \\
\text { that are being shipped. Ensure communication of } \\
\text { expectations is clear with all parties for fuel } \\
\text { element shipment (how many, which ones, etc.). }\end{array}$ \\
\hline $\begin{array}{l}\text { The fuel plates were shipped in Teflon which can } \\
\text { develop a static charge and attract radon. The } \\
\text { problem was unique to this reactor because the } \\
\text { fuel plates had to be shipped individually. }\end{array}$ & $\begin{array}{l}\text { Ensure the T\&FR addresses the customer's } \\
\text { packaging requirements. Identify issues with } \\
\text { Teflon in the T\&FR. }\end{array}$ \\
\hline
\end{tabular}

\subsubsection{Fuel Fabrication data}

The average survey score was 3.00 .

\begin{tabular}{|l|l|}
\hline \multicolumn{1}{|c|}{ Issues } & \multicolumn{1}{|c|}{ Recommendations } \\
\hline $\begin{array}{l}\text { It was difficult to get the fuel fabrication data and } \\
\text { information from the fabricator. The data needs } \\
\text { were not identified in the SOW/contract. }\end{array}$ & $\begin{array}{l}\text { Define the SOW data that will be required by the } \\
\text { reactor, including the customer requirements. } \\
\text { Identify a POC at the fabricator. }\end{array}$ \\
\hline
\end{tabular}

\subsubsection{Preparation of Facility for Fuel Receipt}

The average survey score was 4.5 .

\begin{tabular}{|l|l|}
\hline \multicolumn{1}{|c|}{ Issues } & \multicolumn{1}{|c|}{ Recommendations } \\
\hline $\begin{array}{l}\text { The activity went well, with site personnel aware } \\
\text { of the activities and equipment required. }\end{array}$ & $\begin{array}{l}\text { Having a knowledgeable, experienced POC was } \\
\text { very helpful. } \\
\text { STS was a valuable asset to the process. }\end{array}$ \\
\hline
\end{tabular}

\subsubsection{Fuel Delivery Arrangements (from fabricators to universities)}

The average survey score was 4.67.

\begin{tabular}{|l|l|}
\hline \multicolumn{1}{|c|}{ Issue } & \multicolumn{1}{|c|}{ Recommendation } \\
\hline $\begin{array}{l}\text { Direct contact with the fabricator's shipping } \\
\text { department and the reactor personnel helped } \\
\text { ensure that the transition went smoothly. }\end{array}$ & $\begin{array}{l}\text { Ensure coordination of transportation activities } \\
\text { between the shipper and the receiver. A single } \\
\text { POC at the shipper is desired. }\end{array}$ \\
\hline
\end{tabular}




\subsubsection{Receipt of Containers and Unload New Fuel}

The average survey score was 5.00.

\begin{tabular}{|l|l|}
\hline \multicolumn{1}{|c|}{ Issue } & \multicolumn{1}{|c|}{ Recommendation } \\
\hline $\begin{array}{l}\text { Having personnel familiar with the new fuel } \\
\text { shipping containers improved the process for } \\
\text { receipt of the fuel and return of the empty } \\
\text { containers. }\end{array}$ & Identify a single POC at the shipper. \\
\hline
\end{tabular}

\subsubsection{Perform Receipt Inspection of Fuel}

The average survey score was 3.67.

\begin{tabular}{|l|l|}
\hline \multicolumn{1}{|c|}{ Issue } & \multicolumn{1}{|c|}{ Recommendation } \\
\hline $\begin{array}{l}\text { The fuel inspection process took longer than } \\
\text { anticipated. }\end{array}$ & $\begin{array}{l}\text { Clearly define the purpose of measurement } \\
\text { gauges, such as Go/No-Go gauges, to be used in } \\
\text { the process. If gauges will be used for precise } \\
\text { measurements, rather than gross fit checking, } \\
\text { specify this early so they can be fabricated to the } \\
\text { correct QA level. Include the dimensions in the } \\
\text { T\&FR. }\end{array}$ \\
$\begin{array}{l}\text { Have the QA inspsector present to perform final } \\
\text { inspections before and during packaging of all } \\
\text { shipments. }\end{array}$ \\
\hline
\end{tabular}

\subsubsection{Reassembly Shipping Containers for Return}

The average survey score was 5.00.

\begin{tabular}{|l|l|}
\hline \multicolumn{1}{|c|}{ Issue } & \multicolumn{1}{c|}{ Recommendation } \\
\hline $\begin{array}{l}\text { The right personnel were involved in the receipt } \\
\text { activity with a minimal learning curve. The } \\
\text { required return-shipping information was } \\
\text { available and the process went smoothly. }\end{array}$ & $\begin{array}{l}\text { Allow time early in the process to inform the } \\
\text { reactor personnel about the requirements for } \\
\text { return shipment, including what is in the packages } \\
\text { and what tools will be needed. }\end{array}$ \\
\hline
\end{tabular}

\subsubsection{Fuel Assembly Hardware Receipt and Installation}

The average survey score was 3.67. 


\begin{tabular}{|l|l|}
\hline \multicolumn{1}{|c|}{ Issue } & \multicolumn{1}{c|}{ Recommendation } \\
\hline $\begin{array}{l}\text { The inspector did not have the SOW to determine } \\
\text { the quantity required. }\end{array}$ & $\begin{array}{l}\text { Ensure the inspector has the information he needs } \\
\text { (SOW) to verify quantity and quality. }\end{array}$ \\
\hline
\end{tabular}

\subsection{Core Conversion}

\subsubsection{Removal of Old Fuel and Components}

The average survey score was 4.00 .

\begin{tabular}{|l|l|}
\hline \multicolumn{1}{|c|}{ Issues } & \multicolumn{1}{c|}{ Recommendations } \\
\hline $\begin{array}{l}\text { There was not a firm plan for the receiving site } \\
\text { (SRS) to receive the SNF. Delays occurred } \\
\text { because it was unclear as to what labeling SRS } \\
\text { required. }\end{array}$ & $\begin{array}{l}\text { Initiate the fuel identification/labeling } \\
\text { methodology and be more aggressive with SNF } \\
\text { requirements. }\end{array}$ \\
& $\begin{array}{l}\text { Develop a firm plan for receiving SNF early in the } \\
\text { process, }\end{array}$ \\
\hline
\end{tabular}

\subsubsection{Refueling the Reactor}

The average survey score was 3.00 .

\begin{tabular}{|l|l|}
\hline \multicolumn{1}{|c|}{ Issues } & \multicolumn{1}{c|}{ Recommendations } \\
\hline $\begin{array}{l}\text { The process is time consuming. The reactor } \\
\text { personnel collected more data than was necessary. }\end{array}$ & $\begin{array}{l}\text { Ensure there is a good plan with contingencies } \\
\text { built into the procedures. }\end{array}$ \\
Begin the refueling work as soon as possible. \\
$\begin{array}{l}\text { Share the procedures from other reactors that have } \\
\text { completed the refueling and startup process. }\end{array}$ \\
\hline
\end{tabular}

\subsection{Spent Nuclear Fuel Shipment}

\subsubsection{Identify Shipping Activities}

The average survey score was 4.50 .

\begin{tabular}{|l|l|}
\hline \multicolumn{1}{|c|}{ Issues } & \multicolumn{1}{c|}{ Recommendations } \\
\hline $\begin{array}{l}\text { Using experienced personnel helped the SNF } \\
\text { shipping process to go smoothly. Project } \\
\text { management support was excellent. }\end{array}$ & $\begin{array}{l}\text { Continue with experienced personnel for shipping } \\
\text { activities (STS). }\end{array}$ \\
\hline
\end{tabular}




\subsubsection{SNF Support Contracts with Vendor (STS)}

The average survey score was 5.00.

\begin{tabular}{|l|l|}
\hline \multicolumn{1}{|c|}{ Issues } & \multicolumn{1}{c|}{ Recommendations } \\
\hline $\begin{array}{l}\text { The contracting process worked well for the SNF } \\
\text { support contract. }\end{array}$ & $\begin{array}{l}\text { A base contract with the ability to do releases } \\
\text { worked effectively. }\end{array}$ \\
& $\begin{array}{l}\text { Having a support contractor on site during the } \\
\text { SNF shipments was very helpful. }\end{array}$ \\
\hline
\end{tabular}

\subsubsection{Transportation Plan/Security Plan}

The average survey score was 4.8 .

\begin{tabular}{|c|l|}
\hline \multicolumn{1}{|c|}{ Issue } & \multicolumn{1}{|c|}{ Recommendation } \\
\hline Interfacing with the states for the SNF shipment. & $\begin{array}{l}\text { STS support in dealing with the states was very } \\
\text { helpful. }\end{array}$ \\
\hline
\end{tabular}

\subsubsection{Route Assessment}

The average survey score was 5.0.

\begin{tabular}{|l|l|}
\hline \multicolumn{1}{|c|}{ Issue } & \multicolumn{1}{c|}{ Recommendation } \\
\hline $\begin{array}{l}\text { Early route assessment allowed STS to secure } \\
\text { approval well in advance of the shipment. Early } \\
\text { coordination with all involved parties worked } \\
\text { well. }\end{array}$ & $\begin{array}{l}\text { Conduct the route assessment as early as possible. } \\
\text { Anything being shipped from a new location } \\
\text { needs to have the route assessed as early as } \\
\text { possible. }\end{array}$ \\
\hline
\end{tabular}




\subsubsection{Certification of Reactor Quality Assurance Programs}

The average survey score was 4.0 .

\begin{tabular}{|l|l|}
\hline \multicolumn{1}{|c|}{ Issues } & \multicolumn{1}{|c|}{ Recommendations } \\
\hline $\begin{array}{l}\text { The Radiation Safety Officer did the QA program } \\
\text { certification early in the process, eliminating } \\
\text { problems. }\end{array}$ & $\begin{array}{l}\text { Refer to other experienced universities, such as } \\
\text { MURR (Missouri), for assistance in understanding } \\
\text { the NRC guidance. }\end{array}$ \\
$\begin{array}{l}\text { Provide sample QA programs from other } \\
\text { universities early on so the reactor personnel can } \\
\text { use them as an example and adapt them to their } \\
\text { site-specific needs. }\end{array}$ \\
\hline
\end{tabular}

\subsubsection{Facility Preparations for Spent Nuclear Fuel Activities}

The average survey score was 4.80 .

\begin{tabular}{|l|l|}
\hline \multicolumn{1}{|c|}{ Issue } & \multicolumn{1}{|c|}{ Recommendation } \\
\hline $\begin{array}{l}\text { SNF shipment went well due to the incorporation } \\
\text { of lessons learned from previous conversions and } \\
\text { having STS on site early. }\end{array}$ & $\begin{array}{l}\text { Encourage and facilitate the inclusion of those } \\
\text { involved in SNF activities in early discussions and } \\
\text { preparations. }\end{array}$ \\
\hline
\end{tabular}

\subsubsection{Support Equipment/Tools for Spent Nuclear Fuel Activities}

The average survey score was 4.25.

\begin{tabular}{|l|l|}
\hline \multicolumn{1}{|c|}{ Issues } & \multicolumn{1}{|c|}{ Recommendations } \\
\hline $\begin{array}{l}\text { Lessons learned for close coordination between } \\
\text { the site and STS were incorporated to help the } \\
\text { process run smoothly. }\end{array}$ & $\begin{array}{l}\text { Ensure there is consistency on what is required in } \\
\text { the contract and the level of detail required for an } \\
\text { audit. }\end{array}$ \\
\hline
\end{tabular}

\subsubsection{Appendix A Preparation}

The average survey score was 3.5.

\begin{tabular}{|l|l|}
\hline \multicolumn{1}{|c|}{ Issues } & \multicolumn{1}{|c|}{ Recommendations } \\
\hline $\begin{array}{l}\text { There were problems with getting ORIGEN } \\
\text { (ORNL Isotope Generation and Depletion Code) } \\
\text { to work effectively. Support at the INL resolved } \\
\text { the problem. }\end{array}$ & Identify who has the capability to do reactors \\
\end{tabular}




\subsubsection{Shipping Documentation}

The average survey score was 4.40 .

\begin{tabular}{|l|l|}
\hline \multicolumn{1}{|c|}{ Issues } & \multicolumn{1}{|c|}{ Recommendations } \\
\hline $\begin{array}{l}\text { SNF shipping documents were provided to an } \\
\text { independent reviewer and the states en-route early } \\
\text { in the process for their review and approval. }\end{array}$ & $\begin{array}{l}\text { Continue providing early shipping information to } \\
\text { the universities so the states will be prepared for } \\
\text { inspections, etc. }\end{array}$ \\
\hline
\end{tabular}

\subsubsection{SNF Cask Loading}

The average survey score was 4.80 .

\begin{tabular}{|l|l|}
\hline \multicolumn{1}{|c|}{ Issue } & \multicolumn{1}{|c|}{ Recommendations } \\
\hline $\begin{array}{l}\text { Performing a dry-run of the SNF loading activities } \\
\text { with assigned personnel ensured expedited } \\
\text { loading with minimal exposures. }\end{array}$ & $\begin{array}{l}\text { Continue performing a "dry-run" of loading } \\
\text { activities to identify problems with procedures } \\
\text { and equipment. }\end{array}$ \\
\hline
\end{tabular}

\subsubsection{SNF Receipt Facility Preparation}

The average survey score was 5.00.

\begin{tabular}{|l|l|}
\hline \multicolumn{1}{|c|}{ Issue } & \multicolumn{1}{c|}{ Recommendations } \\
\hline The SNF receipt process worked well. & $\begin{array}{l}\text { Convey the shipping dates to SRS as far in } \\
\text { advance as possible. }\end{array}$ \\
\hline
\end{tabular}

\subsection{Other Issues}

\subsubsection{Safeguarded Information}

The average survey score was 4.67.

\begin{tabular}{|l|l|}
\hline \multicolumn{1}{|c|}{ Issues } & \multicolumn{1}{|c|}{ Recommendations } \\
\hline $\begin{array}{l}\text { The states do not have a clear understanding of } \\
\text { SGI requirements. }\end{array}$ & $\begin{array}{l}\text { An NRC representative will talk with the } \\
\text { organization about informing states about SGI } \\
\text { requirements. }\end{array}$ \\
\hline
\end{tabular}




\section{ROUND ROBIN}

In concluding the discussion of the lessons learned, all participants were invited to reiterate, summarize, or offer any other lessons learned. The following list provides their final thoughts:

- The project lessons learned from previous conversions were incorporated and were valuable in the completion of this conversion.

- $\quad$ There has been good progression from the earliest projects.

- $\quad$ Capturing the lessons learned as early as possible would be helpful for the on-going projects.

- $\quad$ The key to success was that the right people were involved and they had the same goal and worked together to accomplish it.

- Using one project manager for both sides of the project would be helpful. It is difficult for a vendor to serve two masters.

- DOE Headquarters feels that the Purdue conversion was a good project. Thanks to the team for their efforts.

- $\quad$ The INL procurement issue needs to be addressed.

\section{CONCLUSION}

The lessons learned process has allowed us to capture gaps, opportunities, and good practices, drawing from the project team's experiences. The process is inclusive and offers an opportunity for every entity that "touched" the project to share from its experience. These lessons will be used to raise the standard of excellence, effectiveness, and efficiency in all future conversion projects. Despite making improvements to successive projects by addressing the lessons, we have learned on this project, conducting a lessons learned activity will be vital to each conversion project as technologies, regulations, and other aspects of the environment change and influence success. It is recognized we cannot become complacent, nor adopt a mindset that the process has been "perfected." 